\title{
Representasi hubungan keluarga dalam teks film indie "We Need to Talk about Mom"
}

\author{
Riksa Belasunda ${ }^{1}$, Mohamad Tohir ${ }^{2}$, Teddy Hendiawan ${ }^{3}$ \\ ${ }^{1,2,3}$ Universitas Telkom, Bandung, Indonesia
}

\begin{abstract}
ABSTRAK
Komunitas film indie di Bandung berkembang di berbagai lingkungan dan kalangan termasuk dari lingkungan sekolah-sekolah dan kampus-kampus, serta umum. Terdapat beberapa masalah di seputar komunitas film indie dan karya film indie di Bandung, pertama; masalah bagaimana gagasan dan pesan disampaikan dalam karya film indie, kedua; diperlukan upaya lebih jauh untuk dapat memahami, memaknai, dan mengapresiasi teks film indie. Tujuan dari penelitian ini untuk mengetahui bagaimana nilai-nilai keluarga direpresentasikan dalam film "We Need to Talk about Mom" melalui kajian akademis. Penelitian dilakukan dengan menggunakan metode penelitian hermeneutika Paul Ricoeur dengan teknik deskriptif interpretatif berdasarkan tahapan pemahaman; semantik, reflektif, dan eksistensial. Data penelitian berasal dari peserta Bandung \& Santos Film Festival 2017. Jenis film yang diteliti terdiri dari film dokumenter, fiksi, dan eksperimental dengan genre; drama, fantasi, horror, komedi, dan pertualangan. Film indie "We Need to Talk about Mom" yang menjadi sampel objek penelitian dari dua puluh sembilan film indie lainnya, bergenre film fiksi drama. Hasil yang diperoleh dari penelitian ini pertama; Film indie "We Need to Talk about Mom" membangun kesadaran mengenai nilai-nilai "kebersamaan" dalam sebuah keluarga melalui dialog, akomodasi, negosiasi, dan perlawanan. Kedua; Makna eksplisit digambarkan lebih pada penyelesaian masalah antara anak dan ayah dengan berbagai perbedaan pandangan (world view), pola gaya hidup, dan nilai-nilai. Ketiga; Makna implisit merupakan relasionalitas sebagai bentuk aktualisasi dan eksistensi dari kedua tokoh, sedangkan makna reflektif merupakan simbolisasi gaya ungkap kreator, yang merepresentasikan persoalan cinta, gender, dominasi, dan maskulinitas.
\end{abstract}

Kata-kata Kunci: Film indie Bandung; hubungan keluarga; makna film indie; representasi; teks film indie

\section{Representation of family relationships in the indie film text "We Need to Talk about Mom"}

\begin{abstract}
The indie film community in Bandung is growing in various environments and circles, including from schools and campuses, as well as in public. There are several problems surrounding the indie film community and its works in Bandung, including first; The problem of how ideas and messages are conveyed in indie film works, second; Further efforts are needed to be able to understand, interpret, and appreciate indie film texts. The purpose of this study is to find out how family values are represented in the film "We Need to Talk about Mom" through academic studies. The research was conducted using Paul Ricoeur's hermeneutic research method with interpretive descriptive techniques based on the stages of understanding; Semantic, Reflective, and Existential. The research data was obtained from the participants of the Bandung \& Santos Film Festival 2017. The type of films studied were documentary, fiction, and experimental films with genres; Drama, Fantasy, Horror, Comedy, and Adventure. The indie film "We Need to Talk about Mom" became the object of research samples from twenty-nine other indie films, the genre of this film is drama fiction. The results obtained from this study were: First, the indie film "We Need to Talk about Mom" builds awareness about the values of "togetherness" in a family through dialogue, accommodation, negotiation, and resistance. Second, explicit meaning is described more in solving problems between children and father with different world views, lifestyle patterns, and values. Third, the implicit meaning is relationality as a form of actualization and existence of the two characters, while the reflective meaning is a symbol of the creator's style of expression, which represents issues of love, gender, domination, and masculinity.
\end{abstract}

Keywords: Bandung indie film; family relationship; the meaning of indie films; representation; indie film text.

Korespondensi: Dr. Riksa Belasunda, Drs., S.ST., M.Ds. Universitas Telkom. Jalan Telekomunikasi Terusan Buah Batu Bandung 40257. Email: riksab@telkomuniversity.ac.id 


\section{PENDAHULUAN}

Gerakan film independen atau film indie yang disokong oleh komunitas film indie, merupakan sebuah subkultur yang identik dengan perlawanan. Film indie yang berjudul "We Need Talk about Mom" penting dan menarik untuk diteliti berdasarkan sejumlah alasan yaitu: pertama, film "We Need Talk about Mom" memiliki gagasan mengenai nilainilai keluarga; kedua, munculnya ide-ide yang ingin mendefinisikan mengenai keluarga tetapi dalam substansi orientasi anak muda yang ingin diangkatmenjadibagiandariwacanaperlawanan. ketiga, film tersebut merepresentasikan isuisu seperti; ideologi, identitas, dominasi, dan subordinasi; Keempat, Ada keserupaan semangat dari film tersebut yang berbasis pada kesadaran keluarga, yang kemudian wacananya ingin diangkat ke permukaan sebagai bagian dari pertumbuhan identitas anak muda dalam keluarga; Kelima, film "We Need Talk about Mom" telah mengikuti berbagai ajang festival film di Indonesia. Berdasar pada penelitian sebelumnya yang pernah dilakukan oleh Belasunda (2018), tentang Makna dalam Teks Film Indie Bandung Pascareformasi: Sebuah Analisis Hermeneutika. Melihat dari penelitian tersebut menemukan nilai-nilai budaya lokal Sunda mengenai Sineger Tengah dalam film indie karya komunitas film indie Bandung yang memiliki kesamaan dari setiap gagasan dengan sistem formasi sosial sehingga membentuk subkultur.

Subkultur berjuang untuk legitimasi atas kebiasaan, nilai-nilai, dan gaya hidup yang menentang budaya dominan atau kultur mainstream (Barker, 2018). Komunitas film indie mengusung kreativitas dan kebebasan berekspresi yang dituangkan ke dalam media film. Subkultur yang ada dalam film "We Need Talk about Mom" merupakan proses bricolage yakni melakukan proses pemaknaan kembali mengenai tanda, simbol, dan nilai-nilai keluarga melalui media visual. Kemudian dalam film tersebut ada upaya sinkronisasi relasi antara struktur sosial, nilai-nilai sosial, dan simbol kultural yang dipertemukan dalam sebuah keluarga sehingga membentuk homologi yang akan membentuk subkultur. Semangat indie, mendorong individu atau kelompok tidak hanya sebagai penerima informasi, tapi juga sebagai pemberi atau kreator informasi. Komunitas film indie tidak hanya mereka yang mengkreasi film berbeda dari sisi produksi dengan sistem produksi mainstream, tapi juga mempunyai pendekatan yang berbeda dalam menyampaikan gagasan, dan estetika film (Belasunda, 2018).

Estetika pada film sebagai hasil kreasi dari pembuat film secara kolektif yang diterapkan kedalam konsep mise-en-scene. Mengingat aspek-aspek di dalam mise-en-scene ini, mise- 
en-scene merupakan praktik estetik profesional dan sebagai teori atau pendekatan $(H . N$. Hidayat et al., 2021).

Pendekatan dalam hal ini merupakan hubungan dengan kontekstual yang diangkat dalam film tersebut. Film dalam konteks ini bekerja seperti bahasa yang memuat kodekode atau tanda-tanda yang berfungsi untuk memproduksi makna-makna (D. Hidayat et al., 2019).

Komunitas film indie di Bandung berkembang di berbagai lingkungan dan kalangan termasuk dari lingkungan sekolahsekolah dan kampus-kampus, serta umum. Terdapat beberapa masalah di seputar komunitas film indie dan karya film indie di Bandung adalah masalah bagaimana gagasan dan pesan disampaikan dalam karya film indie, untuk itu diperlukan upaya lebih jauh untuk memahami, memaknai, dan mengapresiasi teks film indie.

Film merupakan rangkaian gambar yang diproyeksikan di atas layar dengan kecepatan yang sesuai bertujuan menciptakan ilusi dari gerak yang berkelanjutan (Danesi, 2012). Film sebagai media bertujuan menyampaikan peristiwa/praktik budaya dan fenomena sosial kepada penonton (audiens) luas dengan komunikasi massa melalui sistem media massa. Dalam konteks film sebagai media komunikasi; kreator film berperan sebagai pengirim pesan atau gagasan, penonton film sebagai pembaca gagasan film, dan sebuah karya film sebagai media dimana gagasan itu disampaikan. Secara khusus film juga merupakan sarana untuk mengirimkan atau meneruskan budaya dan media massa juga berkontribusi untuk meneruskan nilai-nilai historis yang ada dalam masyarakat (Febriyanti et al., 2020).

Film sebagai sebuah obyek/artefak terdiri dari struktur fisik dan unsur-unsur pembentuknya. Struktur film terdiri atas shot, adegan, dan sekuen. Unsur-unsur pembentuknya terdiri atas unsur naratif (cerita dan plot, pembabakan, elemen pokok, ruang, waktu, dan informasi cerita) dan unsur sinematik (miseen-scene, sinematografi, editing, dan suara) (Pratista, 2017).

Menurut Hofstede dalam (Aartsen, 2017), secara konseptual, terdapat model konvensi sinematik berdasarkan prinsip produksi dan distribusi film. Model tersebut terdiri dari: (a) Sinema Hollywood, bersifat konvensional (mainstream) dan berfokus pada hiburan.; (b) Sinema Independen (Indie), memiliki format yang unik dan berbeda, kurang komersil dan lebih menitikberatkan pada perolehan kekayaan budaya dan intelektual dan bukan keuntungan finansial. Inovasi menjadi salah satu faktor utama yang akan terus berkembang dalam sinema (film) indie; (c) Sinema Nasional, berorientasi lokal dan tidak ditujukan pada pasar internasional. 
Secara konseptual film indie mempunyai ciri-ciri: (a) Model konvensi sinema independen; film pendek, film eksperimental, film dokumenter; (b) Menitikberatkan pada misi/gagasan; kekayaan budaya dan intelektual, bukan pada keuntungan finansial; (c) Sebagai pergerakan perlawanan terhadap studio besar atau representasi film pinggiran (di luar mainstream), tetapi tidak selalu pada posisi sebagai film non-industri.

Secara konsep film indie mempunyai ciri-ciri: (a) Banyak variasi format, tema, genre, dan gaya ungkap; (b) Mengindikasikan metode dan strategi presentasi ekspresi institusi pembuatnya; (c) Terdapat rentang wacana narasi yang luas, mulai dari wacana narasi film klasik sampai dengan wacana narasi video art; (d) Pendekatan penulis, narator, dan juga penonton (Belasunda, 2018).

Berdasarkan bentuk, film merupakan media komunal yang merupakan penggabungan berbagai teknologi dan beragam unsur kesenian (I. P. Putri, 2017). Termasuk kedalamnya adalah seni peran dan seni pertunjukan (teater dan drama), seni rupa (tata artistik), seni arsitektur, fotografi, dan seni musik. Unsur-unsur tersebut menjadi teks yang membentuk struktur film. Menurut Barker (2018), teks adalah segala sesuatu yang membentuk makna melalui praktik signifikasi. Teks adalah kombinasi tanda-tanda. Unsur-unsur film merupakan tanda-tanda pilihan paradigmatik dan struktur film merupakan kombinasi tanda-tanda (teks) yang membentuk kombinasi sintagma.

Penelitian ini mempunyai tujuan untuk mengetahui bagaimana gagasan dan pesan dari kreator disampaikan dalam teks film indie Bandung. Manfaat Penelitian ini untuk mendukung peningkatan peran aktif dan produktifpenonton film dalam upaya memahami memaknai, dan mengapresiasi karya film indie melalui kajian akademis

\section{METODE PENELITIAN}

Penelitian ini menggunakan metode penelitian hermeneutika Paul Ricoeur dengan teknik deskriptif interpretatif. Metode penelitian ini memiliki tahapan pemahaman; semantik, reflektif, dan eksistensial (Ricoeur, 2012).

Analisis dilakukan dengan mengobjektivikasi struktur teks dengan melakukan analisis struktur (Saidi, 2008). Film sebagai sebuah teks terdiri dari struktur dan unsur-unsur pembentuk film.

Pemahaman semantik akan diketahui melalui konstruksi teks. Pada tahap ini dihasilkan makna eksplisit.

Pemahaman reflektif sudah melampaui batas struktur teks. Pemahaman pada tahap ini berkaitan dengan simbolisasi, referensi, dan relevansi keilmuan. Simbolisasi merupakan gaya ungkap kreator. Makna dalam tahapan 
pemaknaan reflektif adalah unit makna dan struktur makna implisit atau makna tersembunyi.

Pada tahap pemaknaan eksistensial akan dihasilkan makna baru temporer, karena terbuka untuk ketidaksamaan makna bagi setiap penafsir (Ricoeur, 2012).

Objek penelitian berupa sampel yang dipilih berdasarkan tahapan pengambilan data, seleksi data, pembacaan, pendeskripsian, dan pengklasifikasian data. Jenis film yang diteliti terdiri dari film dokumenter, fiksi, dan eksperimental dengan genre; drama, fantasi, horror, komedi, dan pertualangan. Tema besar terdiri atas: (a) Potret dan kritik sosial; budaya dan lingkungan, gender, etnik, dan nasionalisme; (b) hubungan antar individu; persahabatan atau percintaan, keluarga (ayah, ibu, dan anak), pertikaian atau perseteruan antar etnik; (c) individu; berupa pembentukan, pencarian, dan pernyataan identitas diri. Film indie "We Need Talk about Mom" yang menjadi sampel objek penelitian dari dua puluh Sembilan film indie lainnya, bergenre film fiksi drama.

\section{HASIL DAN PEMBAHASAN}

Pengambilan data sebagai objek penelitian berasal dari karya komunitas film indie Bandung dan sekitarnya yang menjadi peserta Bandung \& Santos Film Festival 2017. Festival ini merupakan festival film pendek yang diselenggarakan secara serentak di dua kota yakni Bandung (Indonesia) dan Santos (Brazil). Film yang menjadi peserta festival ini tidak dibatasi tahun produksinya.

Film kaya komunitas film indie Bandung berjumlah 29 karya film indie. Data karya-karya film indie sebagai objek penelitian mempunyai karakteristik yang sangat beragam, baik dari jenis film, genre, gaya ungkap, tema yang diusung, mau pun latar belakang kreator.

Kreator atau pengkarya mayoritas berasal dari komunitas film di lingkungan perguruan tinggi di Bandung, seperti; Cine Club Fikom Unpad, Prodi Televisi dan Film, ISBI Bandung, Multimedia-DKV Telkom University, Saluran Film Institut Kesenian Jakarta, Liga Film Mahasiswa ITB, Videografi LFM, di samping karya komunitas film indie umum di Bandung. Tahun produksi antara tahun 2012 sampai dengan tahun 2017.

Jenis film yang dihasilkan terdiri dari film dokumenter, fiksi, dan eksperimental dengan genre; drama, fantasi, horror, komedi, dan pertualangan. Tema besar terdiri atas: (a) Potret dan kritik sosial; budaya dan lingkungan, gender, etnik, dan nasionalisme; (b) hubungan antar individu; persahabatan atau percintaan, keluarga (ayah, ibu, dan anak), pertikaian atau perseteruan antar etnik; (c) individu; berupa pembentukan, pencarian, dan pernyataan identitas diri.

Seleksi data untuk mendapatkan sampel 
sebagai objek penelitian dilakukan berdasarkan tema dominan, bentuk dan gaya ungkap film. Jenis film fiksi bergenre drama dan tema hubungan antar individu menjadi film dominan dalam data penelitian. Dari data sebanyak 29 film indie karya komunitas film indie Bandung dengan tema dominan, bentuk dan gaya ungkap, film indie dengan judul "We Need Talk about Mom" produksi Anticipa Pict dari Prodi Televisi dan Film Institut Seni Budaya Indonesia (ISBI) Bandung tahun 2017 dipilih menjadi sampel objek penelitian. Film ini berisi konten hubungan keluarga antara anak (perempuan) dan ayahnya, setelah ditinggal istri atau ibunya yang menyimpan permasalahan diantara mereka. Film ini merupakan film fiksi bergenre drama dengan durasi 13 menit 02 detik.

Tokoh atau karakter Ayah diperankan oleh Adam Panji sedangkan karakter Ain diperankan oleh Putri Aina. Film ini disutradarai oleh Ahmad Augi, Regiansyah sebagai penulis naskah, dan Beto Maharsidik sebagai director of photography.

Struktur film yang terdiri atas sekuen, adegan, dan shot didukung oleh unsur-unsur naratif dan unsur-unsur sinematik. Unsur-unsur naratif terdiri atas; cerita dan plot, pembabakan, elemen pokok, ruang, waktu, dan informasi cerita. Unsur-unsur sinematik terdiri atas; mise-en-scene, sinematografi, editing, dan suara. Unsur-unsur tersebut adalah teks yang membentuk struktur film. Teks ini yang akan membentuk makna melalui praktik signifikasi.

Analisis struktur teks terdiri atas analisis struktur naratif dan analisis unsur sinematik film. Struktur naratif film "We Need Talk about Mom", menggunakan penuturan tiga babak dengan struktur konvensional, yakni babak satu atau fase eksposisi, babak dua atau fase komplikasi, dan babak tiga atau fase resolusi.

Tokoh atau karakter Ayah diperankan oleh Adam Panji sedangkan karakter Ain diperankan oleh Putri Aina. Film ini disutradarai oleh Ahmad Augi, Regiansyah sebagai penulis naskah, dan Beto Maharsidik sebagai director of photography.

Fase eksposisi, dimulai saat ayah mengajak Ain untuk pergi kemah bersama. Sang ayah terlihat sangat memahami Ain dan tahu segalanya tentang Ain. Sang ayah sengaja memilih tempat yang penuh dengan panorama dan alam, meskipun Ain sedikit tidak menyukai tempat tersebut. Pembicaraan dimulai dengan pertanyaan keseharian Ain dan ayah yang penasaran tentang Ain yang belum memiliki pasangan, Ain dengan gaya tomboy-nya mulai menyalakan api dan merokok bersama ayahnya.

Fase komplikasi, ketika Ayah mulai meminta Ain untuk tinggal bersama dengannya, berikut penjelasan tentang surat-surat yang akan diurus dan rencana tentang kehidupan Ain kedepannya. Ain dengan nada jutek-nya 
menyindir sang ayah yang dirasa janggal karena telah memperhatikan orang lain. Pembahasan tentang Ibu dimulai ketika musik Led Zeppelin diputar. Sampai titik ini sosok sang ibu masih seolah baik-baik saja dan keberadaannya juga tidak diceritakan. Titik emosi tertinggi tercurah ketika Ain mengatakan "Kalau ayah udah maapin ibu, kenapa ayah gak dateng ke pemakaman ibu?!", ekspresi haru dan kesal bercampur ada pada wajah Ain dan sang ayah.

Fase resolusi, dimulai ketika Ayah bertanya kepada Ain tentang salahkah jika salah satu dari sepasang kekasih menyimpan rahasia yang rumit selama bertahun-tahun, dan ketika kembali pasangan tersebut hanya menjelaskan sesuatu yang rumit tersebut dengan begitu saja. Ain yang tidak mengerti akan hal itu memaksa sang ayah untuk menceritakan hal rumit itu dengan sebenarnya. Ayah yang sudah tidak kuat untuk menahan hal tersebut akhirnya menceritakan semuanya dengan rasa kesedihan yang sangat dalam. Ain akhirnya mengetahui hal tersebut dan membutuhkan waktu untuk meredam rasa marah dan sedih.

After credits scene menggambarkan tentang rasa khawatir Ain mengenai perasaan ayahnya yang sangat hancur pada waktu itu. Ain menuturkan permintaan maaf pada ayah untuk ibunya, akhirnya mereka berdua sepakat untuk bersama lagi dengan syarat guyon jika sang ayah tak boleh melarang Ain untuk merokok.
Latar atau setting film "We Need Talk about Mom" mengacu pada tempat, hubungan waktu dan lingkungan sosial tempat terjadinya cerita. Cerita selalu menempati ruang dan waktu, latar tidak hanya terkait dengan geografis temporal semata, melainkan juga mempunyai makna sosiologis, seperti tradisi, keyakinan, ideologi dan yang lainnya. Dalam film "We Need Talk about Mom" latar pemandangan alam digunakan sebagai upaya alternatif dalam menyelesaikan masalah antara anak dan orangtua.

Gagasan atau konsep naratif dalam film "We Need Talk about Mom" membangun kesadaran akan pentingnya "kebersamaan" dalam sebuah keluarga melalui perlawanan dengan cara melakukan pembalikan nilai dan evaluasi nilai. Visi dalam film tersebut ingin menyampaikan tentang perbedaan sudut pandang mengenai nilai-nilai yang ada dalam sebuah keluarga. Identifikasi dalam naratif film "We Need Talk about Mom" melakukan pembalikan dan evaluasi nilai mengenai sebuah pandangan (wold view), pola gaya hidup, dan pengetahuan yang mengubah identitas dari kedua karakter yakni Ain dan ayahnya.

Analisis teks film selain unsur naratif juga analisis atas unsur sinematik yang terdiri dari mise-en-scene, sinematografi, editing, dan suara termasuk kedalamnya adalah narasi visual dari film tersebut. Berikut Analisis Teks Visual dan Semantik Film “We Need Talk about Mom”: 


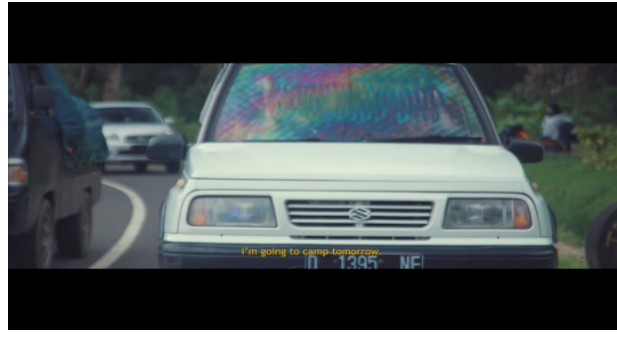

Sumber: We Need Talk about Mom, 2017

Gambar 1 Ain dan Ayahnya di dalam mobil.

Mise-en-scène pada fase eksposisi menggunakan setting shot on location untuk membangkitkan efek realisme supaya terlihat aktual. Adegan ini juga merupakan establishing shot untuk memberikan gambaran umum dari setiap tokoh. Properti mobil menunjukan status sosial dan memberikan kesan macho dengan menggunakan mobil jeep. Penerapan aspek sinematografi yang digunakan adalah following shot / dolly out dan sudut pandang kamera straight angle. Sedangkan teknik pencahayaan menggunakan available light yakni menggunakan cahaya yang telah tersedia secara otomatis di lingkungan sekitar untuk menegaskan sebuah bentuk dari objek. Editing yang digunakan hanya transisi cut to cut dari Fase pembuka dari Sekuen (S1)-Adegan (A)1 ke Sekuen (S)1 - Adegan (A)2, serta penggunaan warna lebih natural untuk mengesankan dingin. Pergerakan karakter non manusia yakni objek mobil. Mise-en-scène menggunakan setting shot on location suasana di dalam mobil, kostum yang digunakan oleh tokoh Adam (ayah)

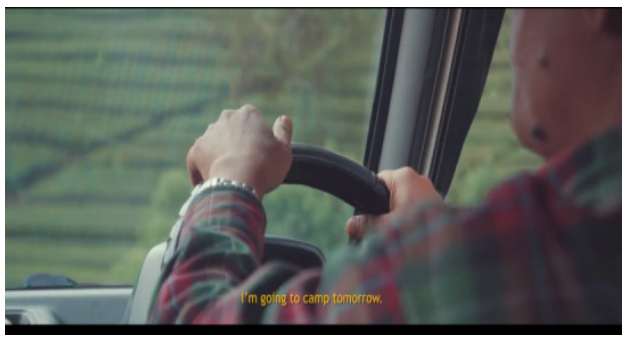

Sumber: We Need Talk about Mom, 2017

Gambar 2 Tokoh Adam (ayah) sedang mengemudi.

menggunakan kemeja flanel yang memiliki ciri baju seorang pendaki gunung dan penegasan status sosial.

Penerapan aspek sinematografi pada scene menggunakan overshoulder shot, handheld dan sudut pandang kamera straight angle. Editing menggunakan transisi cut to cut dari $\mathrm{S} 1-\mathrm{A} 2$ ke S1- A3, serta penggunaan warna lebih natural untuk mengesankan dingin. Sedangkan teknik pencahayaan menggunakan available light yakni menggunakan cahaya yang telah tersedia secara otomatis di lingkungan sekitar dan ditambah dengan arah frontal lighting untuk menegaskan sebuah bentuk dari objek. Pergerakan karakter nonmanusia yakni objek mobil dan karakter manusia tokoh Adam (ayah).

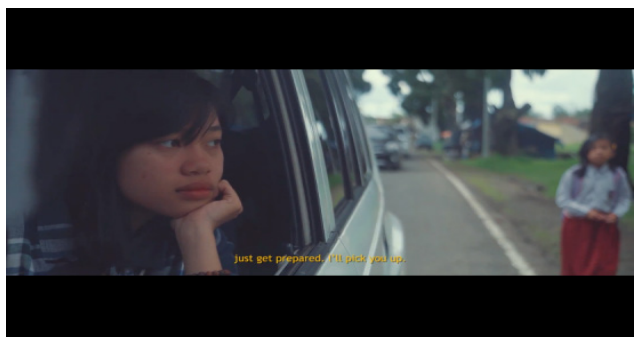

Sumber: We Need Talk about Mom, 2017

Gambar 3 Ain sedang termenung di dalam mobil. 
Mise-en-scène: setting shot on location memperjelas keadaan lokasi dan kondisi perjalanan tokoh Ain. kostum dan make-up tokoh Ain menggunakan kemeja flanel untuk menggambarkan kesan tomboy seperti lakilaki dan penegasan status sosial. Kemeja flanel tersebut biasa digunakan secara umum bagi para laki-laki yang akan berangkat mendaki gunung atau pendaki. Penerapan aspek sinematografi dengan angle close up, framing dan sudut pandang kamera straight angle untuk penegasan terhadap subyek atau tokoh Ain dalam mengungkapkan statement yang ada dalam pikirannya. Sedangkan teknik pencahayaan menggunakan available light yakni menggunakan cahaya yang telah tersedia secara otomatis di lingkungan sekitar untuk menegaskan ekspresi tokoh yang termenung. Pergerakan lebih pada nonmanusia yakni pergerakan kendaraan mobil. Editing menggunakan transisi cut to cut dari $\mathrm{S} 1-\mathrm{A} 3$ ke S2- A1, serta pengunaan warna yang lebih natural untuk mengesankan dingin. Pergerakan karakter manusia di dalam kendaraan.

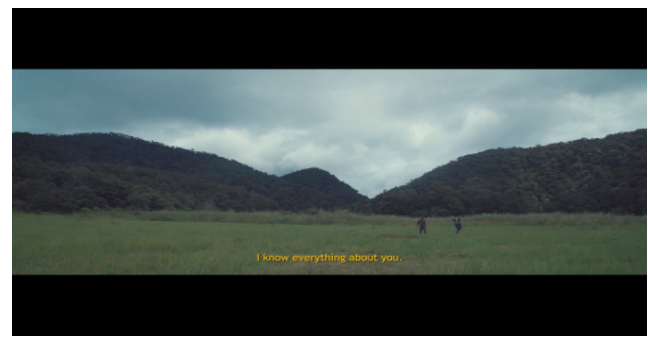

Sumber: We Need Talk about Mom, 2017

Gambar 4 Ain dan ayahnya berjalan ditengah pegunungan.
Mise-en-scène: setting shot on location untuk memperjelas suasana dan kondisi dari setiap tokoh. Penggunaan objek natural seperti pemandangan alam sebagai pemecahan masalah bagi tokoh Adam. Kostum yang digunakan oleh Ain dan Ayahnya menggunakan kostum yang digunakan oleh para pendaki gunung yang sekaligus membentuk identitas tokoh Ain dan ayahnya, serta sekaligus menentukan status sosial. Penggunaan aspek sinematografi menggunakan angle extra long shot untuk mempertegas dan memperlihatkan kekuatan visual objek pemandangan, serta penggunaan sudut pandang kamera strait angle membuat kesan kesetaraan. Sedangkan teknik pencahayaan menggunakan available light yakni menggunakan cahaya yang telah tersedia secara otomatis di lingkungan sekitar untuk menegaskan sebuah bentuk dari objek. Editing menggunakan transisi cut to cut dari $\mathrm{S} 2-\mathrm{A} 2 \mathrm{ke}$ S3- A1, dan menggunakan warna natural untuk mengesankan dingin, luas, dan kedalaman. Pergerakan tokoh Ain dan ayahnya dari arah kanan ke kiri menunjukan pertentangan.

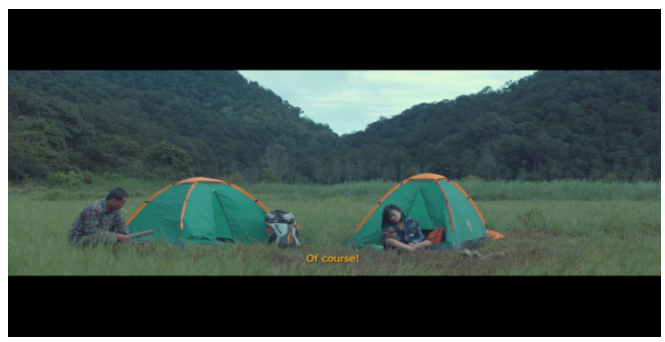

Sumber: We Need Talk about Mom, 2017

Gambar 5 Ain dan ayahnya sedang berbincang. 
Mise-en-scène: Setting shot on location untuk memperjelas suasana dan kondisi dari setiap tokoh. Penggunaan objek natural alam untuk penunjuk ruang dan waktu sebagai tempat dimana bisa berkomunikasi dengan baik antara Ain dan Ayahnya. Kostum yang digunakan oleh Ain dan Ayahnya adalah kostum yang digunakan oleh para pendaki gunung yakni kemeja flanel dan celana khusus pendaki, serta properti seperti peralatan camping dan tenda menunjukan status sosial. Penerapan aspek sinematografi menggunakan angle long shot, still, dan sudut pandang kamera high angle serta menggunakan komposisi simetrik untuk mengesankan kekosongan dan ketertutupan atau tidak terbuka. Sedangkan teknik pencahayaan menggunakan available light yakni menggunakan cahaya yang telah tersedia secara otomatis di lingkungan sekitar untuk menegaskan sebuah bentuk dari objek. Editing menggunakan transisi cut to cut dari S3-A2 ke S3- A3, dan menggunakan warna natural untuk mengesankan dingin, luas, dan kedalaman. Tidak ada pergerakan tokoh, hanya saling bertatapan.

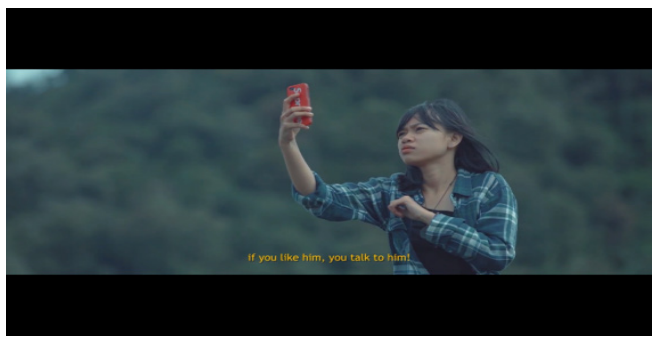

Sumber: We Need Talk about Mom, 2017
Mise-en-scène: setting shot on location untuk memperjelas suasana dan kondisi dari setiap tokoh. Kostum yang digunakan oleh Ain menggunakan kostum yang digunakan oleh para pendaki gunung yakni menggunakan kemeja flanel, serta penggunaan properti seperti alat komunikasi menunjukan status sosial. Penerapan aspek sinematografi menggunakan medium shot dan depth of field sebagai penguat karakter atau simbolisasi, serta penggunaan sudut pandang kamera low angle untuk memberikan kesan keras, bebas, dan kritis. menggunakan teknik Sedangkan teknik pencahayaan menggunakan available light yakni menggunakan cahaya yang telah tersedia secara otomatis di lingkungan sekitar untuk menegaskan sebuah bentuk dari objek. Editing menggunakan transisi cut to cut dari S3-A3 ke S3- A4, dan menggunakan warna natural untuk mengesankan dingin, dan kedalaman. Pergerakan yang dilakukan oleh tokoh hanya mencari sinyal dari alat komunikasi yang dipakai oleh tokoh Ain.

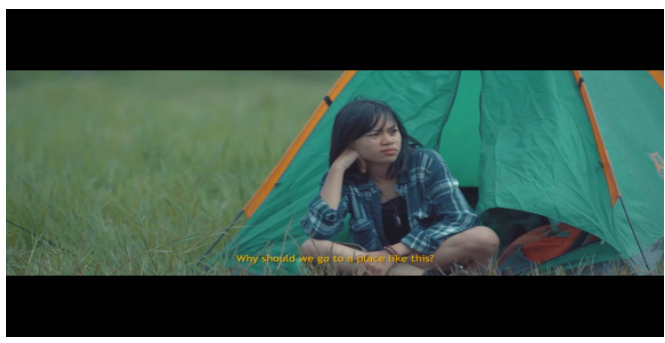

Sumber: We Need Talk about Mom, 2017

Gambar 7 Ain termenung sambil melihat alam sekitar.

Gambar 6 Ain sedang mencari sinyal handphone. 
Mise-en-scène: setting shot on location untuk memperjelas suasana dan kondisi dari setiap tokoh. Kostum yang digunakan oleh Ain menggunakan kostum yang digunakan oleh para pendaki gunung yakni menggunakan kemeja flanel, lengkap dengan jenis celana dan sepatunya. Penggunaan properti alat-alat kamping dan tenda menunjukan status sosial. Penerapan aspek sinematografi menggunakan angle Full shot, eye level, still, dan penggunaan sudut pandang kamera high angle untuk memberi kesan kebingungan dan kegamangan dari tokoh Ain. Sedangkan teknik pencahayaan menggunakan available light atau ambient light yakni menggunakan cahaya yang telah tersedia secara otomatis di lingkungan sekitar untuk memperkuat sebuah bentuk dari objek. Editing menggunakan transisi cut to cut dari S3-A4 ke S3- A5, dan menggunakan warna natural untuk mengesankan dingin, tenang, dan kedalaman. Pergerakan tokoh Ain hanya memandang alam sekitar pegunungan.

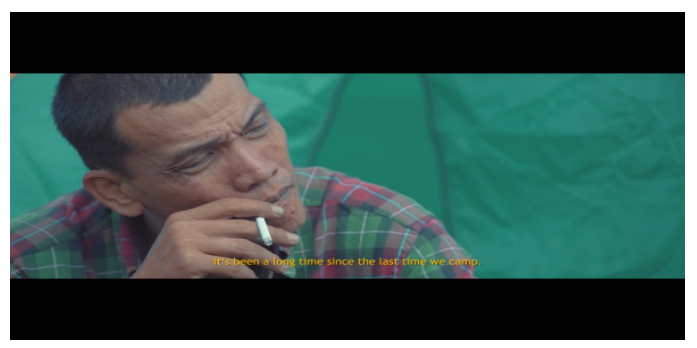

Sumber: We Need Talk about Mom, 2017

Gambar 8 Adam (ayah) sedang termenung sambil merokok.
Mise-en-scène: setting shot on location untuk memperjelas suasana dan kondisi dari setiap tokoh. Kostum yang digunakan oleh Adam (ayah) menggunakan kostum yang digunakan oleh para pendaki gunung pada umumnya yakni menggunakan kemeja panel. Penggunaan properti rokok untuk menegaskan kesan laki-laki, macho. dan bebas. Penerapan aspek sinematografi menggunakan angle close up, handheld, dan penggunaan sudut pandang kamera high angle untuk menguatkan statement subyek yang menggambarkan ekspresi kebingungan dan kegamangan sedangkan teknik pencahayaan selain menggunakan ambient light yakni menggunakan cahaya yang telah tersedia secara otomatis di lingkungan sekitar juga ditambah dengan arah frontal lighting untuk memperjelas ekspresi dari tokoh. Editing menggunakan transisi cut to cut dari S3-A5 ke S3- A6, dan menggunakan warna natural untuk mengesankan dingin, tenang, dan kesan kedalaman. Pergerakan tokoh Adam hanya merokok dan merenungkan sesuatu.

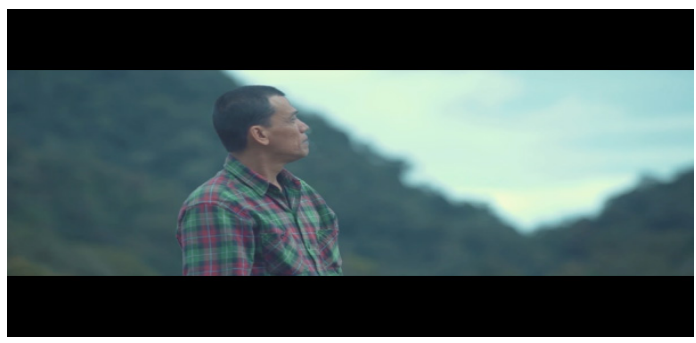

Sumber: We Need Talk about Mom, 2017

Gambar 9 Adam (ayah) sedang memandang alam. 
Mise-en-scène: setting shot on location untuk memperjelas suasana dan kondisi dari setiap tokoh. kostum yang digunakan oleh Adam (ayah) menggunakan kostum yang digunakan oleh para pendaki gunung pada umumnya yakni menggunakan kemeja flanel. Penerapan aspek sinematografi menggunakan angle medium shot dan penggunaan sudut pandang kamera low angle untuk menunjukan kegagahan tokoh dan kemegahan alam, sedangkan teknik pencahayaan selain menggunakan ambient light yakni menggunakan cahaya yang telah tersedia secara otomatis di lingkungan sekitar juga ditambah dengan arah frontal lighting untuk memperjelas ekspresi dari tokoh. Editing menggunakan transisi cut to cut dari S3-A6 ke S4- A1, dan menggunakan warna natural untuk mengesankan dingin, tenang, dan kesan luas. Pergerakan tokoh Adam hanya melihat dan mengamati pemandangan alam disekitarnya.

Mise-en-scène pada fase eksposisi menggunakan setting shot on location untuk

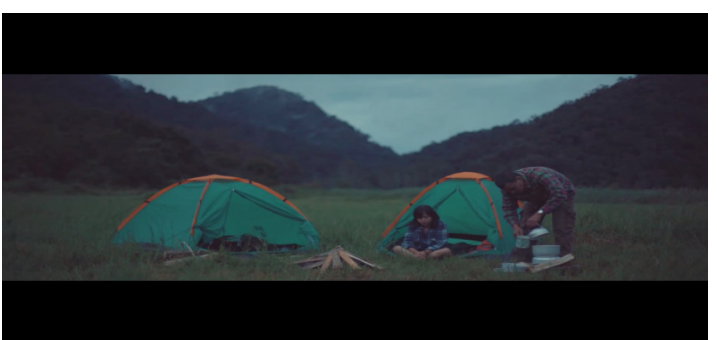

Sumber: We Need Talk about Mom, 2017

Gambar 10 ayah sedang mengambil air. membangkitkan efek realisme supaya terlihat lebihaktualdanobyeknaturalpemandanganalam memiliki sistem nilai. kostum yang digunakan oleh Ain dan ayahnya menggunakan kostum yang digunakan oleh para pendaki gunung pada umumnya yakni menggunakan kemeja flanel, celana, dan sepatu yang sesuai dengan peruntukannya. Penggunaan properti alat-alat masak dan tenda menunjukan status sosial. Penerapan aspek sinematografi menggunakan eye level, long shot/ two shot, dan penggunaan sudut pandang kamera high angle. Sedangkan teknik pencahayaan selain menggunakan ambient light yakni menggunakan cahaya yang telah tersedia secara otomatis di lingkungan sekitar. Editing menggunakan transisi cut to cut dari S4-A1 ke S4- A2, dan menggunakan warna natural untuk mengesankan dingin, tenang, dan kesan luas. Pergerakan tokoh adam mengambil air minum dan memberikannya pada tokoh Ain. Mise-en-scène: setting shot on location untuk memperjelas suasana dan kondisi dari

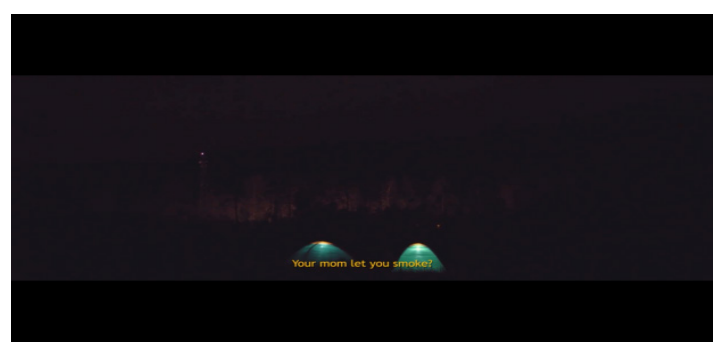

Sumber: We Need Talk about Mom, 2017

Gambar 11 Suasana tenda Ain dan ayah di malam hari. 
setiap tokoh. Penerapan aspek sinematografi menggunakan angle extra long shot, eye level dan penggunaan sudut pandang kamera high angle serta mengggunakan komposisi simetrik untuk memperlihatkan motif keterasingan, terperangkap dan tertutup. Sedangkan teknik pencahayaan selain menggunakan available light atau ambient light yakni menggunakan cahaya yang telah tersedia secara otomatis di lingkungan sekitar juga ditambah dengan artificial lighting yakni diberikan tambahan cahaya melalui lampu senter dengan arah pencahayaan top lighting untuk memberikan kesan dingin. Editing menggunakan transisi cut to cut dari S4-A2 ke S4- A3, dan menggunakan warna natural untuk mengesankan dingin, tenang, dan kesan kedalaman. Tidak ada pergerakan dari kedua tokoh Ain dan Ayahnnya.

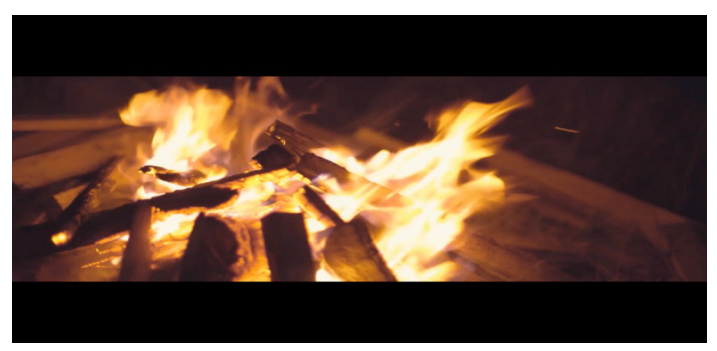

Sumber: We Need Talk about Mom, 2017

Gambar 12 Api unggun.

Mise-en-scène: setting shot on location untuk memperjelas suasana dan obyek yang diambil yakni obyek kultural dimana api unggun dimaknai mempererat hubungan, percaya diri, dan keberanian. Penerapan aspek sinematografi menggunakan angle extreme close up, detail shot dan penggunaan sudut pandang kamera high angle untuk memberikan kesan hangat. Sedangkan teknik pencahayaan menggunakan artificial lighting yakni diberikan tambahan cahaya melalui api ungun untuk memberikan kesan hangat. Editing menggunakan transisi cut to cut dari S4-A3 ke S4- A4, dan menggunakan warna natural untuk mengesankan hangat, tenang, dan penyelesaian.

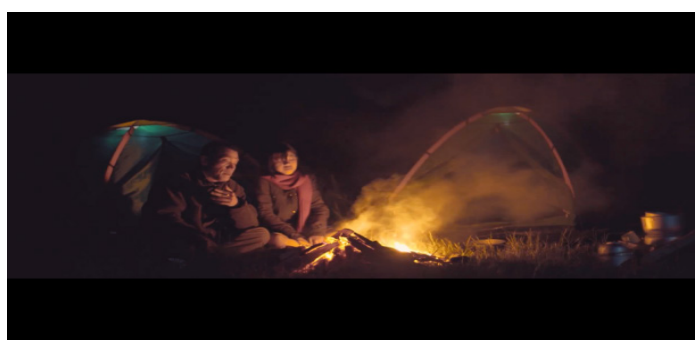

Sumber: We Need Talk about Mom, 2017

Gambar 13 Ain dan ayah di depan api unggun.

Mise-en-scène: setting shot on location untuk memperjelas suasana dan kondisi dari setiap tokoh, make-up, art directory. Setting yang dibangun secara realis untuk membentuk mood dari setiap tokoh yakni Ain dan ayahnya. kostum yang digunakan oleh Ain dan Adam (ayah) menggunakan mantel atau jaket dan sal untuk melindungi diri dari angin. Kostum yang digunakan juga sebagai penunjuk status sosial dan identitas dari kedua tokoh. Penerapan aspek sinematografi melalui angle full shot, eye level dan penggunaan sudut pandang kamera high angle untuk membangun suasana 
kebersamaan. Sedangkan teknik pencahayaan selain menggunakan available light atau ambient light yakni menggunakan cahaya yang telah tersedia secara otomatis di lingkungan sekitar juga ditambah dengan artificial lighting yakni diberikan tambahan cahaya melalui arah pencahayaan under lighting seperti api unggun untuk memberikan kesan hangat. Editing menggunakan transisi cut to cut dari S4-A3 ke S4- A4. Pergerakan tokoh hanya saling berdialog antara tokoh Ain dan ayah.

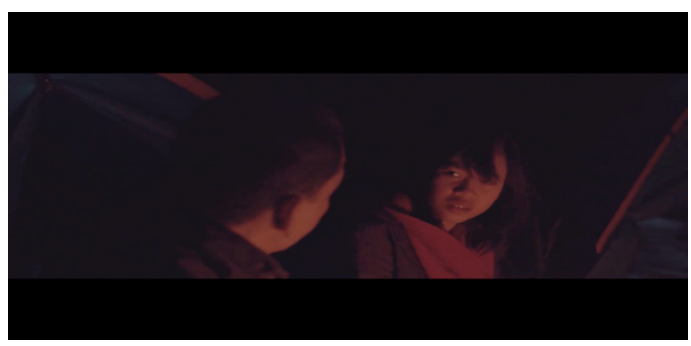

Sumber: We Need Talk about Mom, 2017

Gambar 14 Suasana Ain dan ayah sedang bercerita.

Mise-en-scène: setting shot on location untuk memperjelas suasana dan kondisi dari setiap tokoh dan membangun mood. Penerapan aspek sinematografi menggunakan angle over shoulder, still, dan straight angle memberikan kesan keakraban, sejajar, dan kedekatan diantara kedua tokoh Ain dan ayahnya. Sedangkan teknik pencahayaan selain menggunakan available light atau ambient light yakni menggunakan cahaya yang telah tersedia secara otomatis di lingkungan sekitar juga ditambah dengan artificial lighting yakni diberikan tambahan cahaya melalui arah pencahayaan under lighting seperti api unggun untuk memberikan kesan hangat. Editing menggunakan transisi cut to cut dari S4-A4 ke S4-A5., dan menggunakan warna natural untuk mengesankan dingin, tenang, dan kedalaman. Pergerakan hanya saling menatap ketika kedua tokoh berdialog atau berbicara.

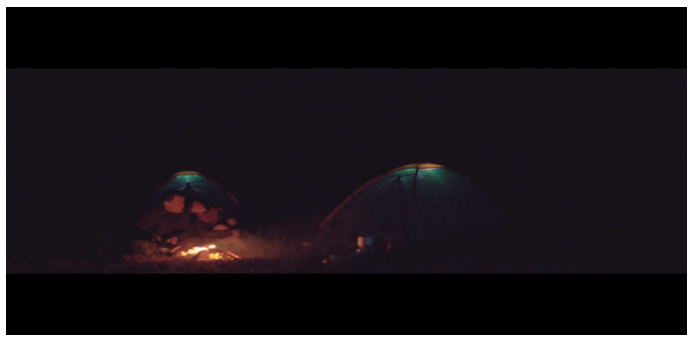

Sumber: We Need Talk about Mom, 2017

Gambar 15 Suasana bahagia Ain dan ayah.

Mise-en-scène: setting shot on location untuk memperjelas suasana dan kondisi dari setiap tokoh. kostum yang digunakan oleh Ain dan Adam (ayah) menggunakan mantel atau jaket dan sal untuk melindungi diri dari kondisi malam yang angin. Kostum yang digunakan penunjuk status sosial dari kedua tokoh. Penerapan aspek sinematografi menggunakan angle Long shot, two shot, dan still. Sedangkan teknik pencahayaan selain menggunakan available light atau ambient light yakni menggunakan cahaya yang telah tersedia secara otomatis di lingkungan sekitar juga ditambah dengan artificial lighting yakni diberikan tambahan cahaya melalui api unggun untuk memberikan kesan hangat. Editing 
menggunakan transisi cut to cut dari S4-A5 ke S5- A1, dan menggunakan warna natural untuk mengesankan kehangatan, tenang, dan kedalaman. Pergerakan tokoh hanya pergerakan tokoh Ain menyandarkan kepala di pundak ayahnya.

Keseluruhan aspek sinematik tersebut merupakan bentuk manifestasi simbolik. Unsur simbolik dalam mise-en-scene menggunakan kostum casual pendaki yakni mulai dari baju, celana, sepatu yang secara umum digunakan oleh para lelaki, merupakan bentuk representasi maskulinitas. Setting properti dengan menggunakan mobil jeep, peralatan masak, tenda dan suasana alam pegunungan yang menggambarkan sebuah kekuatan. Penggunaan lanskap alam juga untuk menunjukan bahwa alam yang kuat merupakan dunia seorang laki-laki. Tokoh ayah berupaya menunjukan bahwa dengan menguasai alam maka akan menyelesaikan masalah yang dihadapi.

Bahasa sinematografi dengan penggunaan close-up danmediumclose-up untukmenunjukan steatment subjek dalam mengartikulasikan sesuatu yang lebih khusus pada pernyataan tokoh Ain dan ayahnya. Penekanan dengan teknik depth of field untuk membuat kekuatan simbol pada setiap tokoh. Pergantian dari close-up ke medium- close-up memberi reaksi terhadap apa yang dikatakan atau dilakukan oleh tokoh Ain dan ayahnya. Sedangkan angle yang digunakan melalui titik pandang pengontrasan (contrasting angle) yakni penggunaan angleangle kamera dalam arah bertentangan satu sama lain dan pengulangan (repetitious angle), yang menggunakan angle yang bersamaan digunakan terhadap subjek yang sama dengan yang lain untuk menggambarkan perselisihan atau pertentangan antara setiap subyek untuk menyampaikan relasi dari setiap tokoh.

Dalam film "We Need Talk about Mom" penggunaan kontiniti waktu hanya bergerak kedepan secara kronologis dan kontiniti ruang digunakan untuk menuturkan cerita yang bergerak dari satu tempat ke tempat lainnya. Sedangkan kontiniti kondisi (conditional time) tidak diungkapkan melalui visual, akan tetapi melalui dialog verbal secara langsung sebagai penggambaran sikap mental dan perilaku tokoh Ain dan ayahnya dalam melihat suatu peristiwa, atau suatu kenangan, imajinasi, atau melalui tokoh Ain dan ayahnya dalam "melihat" suatu peristiwa dalam suatu ketidakberesan pada mata hatinya.

Screen direction dinamis atau tubuh bergerak, pertama digunakan screen direction netral yang ditampilkan melalui visual mobil bergerak secara lurus ke depan atau kearah penonton. Kedua, digunakan screen direction pengontrasan yakni kedua-dua kiri-ke-kanan dan kanan-ke-kiri. Pergerakan tersebut digunakan secara berbeda dengan yang sering 
digunakan dalam beberapa film yang lain.

Screen direction kedatang diambil atau dimulai dari arah kanan, yang secara umum biasanya dimulai dari arah kiri ini menunjukan film tersebut mau mengkritisi atau sebagai sebuah perlawanan yang disampaikan melalui tokoh Ain dan ayahnya.

Analisis struktural teks sebagai tahapan pemahaman semantik menghasilkan makna eksplisit. Makna eksplisit dari film "We Need Talk about Mom" adalah sebagai berikut: (a) Karakter Ain keberatan diajak ayahnya untuk kemping, karena merasa tidak nyaman untuk berada di tempat seperti itu; (b) Karakter Ayah mengajak Ain kemping sekaligus untuk bernostalgia untuk mengingat masa lalu di antara mereka; (c) Karakter Ain menganggap ayahnya tidak bertanggung jawab meninggalkan dia dan ibunya; (d) Karakter Ayah menjelaskan apa yang terjadi pada dirinya selama bertahun tahun menikah dengan ibunya; (e) Karakter Ain akhirnya ingin hidup bersama dengan ayahnya, tapi dengan satu syarat sambil bercanda; (f) Karakter Ayah hanya tersenyum untuk bisa mengakomodir apa yang Ain inginkan.

Tahapan selanjutnya adalah pemahaman reflektif yang berkaitan dengan simbolisasi sebagai gaya ungkap kreator, serta referensi dan relevansi keilmuan dari penafsir. Makna yang akan dihasilkan pada tahapan ini adalah unit makna dan struktur makna implisit atau makna tersembunyi. Pemaknaan yang dihasilkan pada tahapan ini berkaitan dengan patriarki dan relasi gender. Gender merupakan konsep kultural yang dijadikan parameter perbedaan (distinction) dalam hal peran, perilaku, mentalitas, dan karakteristik emosional antara laki-laki dan perempuan yang didasarkan pada pengaruh sosial budaya masyarakat (social construction) (Sutorini et al., 2019).

Makna implisit yang dihasilkan dari unit makna adalah: (a) Karakter Ain sebagai representasi generasi muda yang ingin menunjukkan identitas dan eksistensinya di antara paradigma atau nilai-nilai yang ada dan berlaku dalam masyarakat; (b) Karakter Ayah sebagai representasi dari seorang ayah maskulin, sabar dan bijak dan juga seorang yang suka adventure dengan kekuatan alam, sekaligus berupaya menawarkan pengalaman dan nilai-nilai kehidupan terhadap karakter Ain; (c) Karakter Ayah berpikir bahwa dengan cara menyatu dengan alamlah kita bisa menyelesaikan segala masalah, karena alam mempunyai kekuatan; (d) Karakter Ain berpikir pragmatis, artinya dia hanya mengandalkan apa yang dilihat oleh kasat matanya ketika ayahnya meninggalkan keluarga; (e) Karakter Ayah lebih menekankan pada pengalaman subjektif untuk memberikan pemahaman akan nilai-nilai pada karakter Ain; (f) Karakter Ain mencoba menegosiasikan dan mendialogkan 
tentang nilai-nilai kebebasan pada ayahnya; (g) Karakter Ayah merepresentasikan seorang yang memiliki kesetiaan, komitmen terhadap ibu Ain.

Makna implisit atau makna tersembunyi dari objek penelitian ini memperlihatkan bagaimana sebuah permasalahan diselesaikan dengan pendekatan dialogis. Bagaimana paradigma atau nilai-nilai yang ada dan berlaku dalam masyarakat dikomunikasikan secara terbuka oleh pihak-pihak yang meyakini nilainilai kebenarannya masing-masing. Dalam konteks budaya patriarki dan relasi gender, hubungan keluarga antara ayah dan anak perempuannya; Ayah dan Ain memperlihatkan prinsip kebenaran yang mereka pilih. Melalui dialog diantara mereka dapat diketahui sejauh mana pandangan-pandangan atas kebenaran dan bagaimana Ayah dan Ain mengkomunikasikan kebenarannya masing-masing.

Tahapan akhir adalah pemahaman eksistensial yang akan menghasilkan makna baru temporer. Pemaknaan ini terbuka untuk ketidaksamaan makna bagi setiap penafsir pada ruang dan waktu yang berbeda (Ricoeur, 2012). Makna eksistensial atau makna baru temporer film "We Need Talk about Mom": (a) Hubungan relasionalitas antara karakter ayah dan karakter Ain merupakan perbedaan paradigma dan sistem nilai. Dalam fase eksposisi pada adegan tersebut karakter Ain lebih menggunakan pengalaman objektif, yakni terkait dengan keputusan yang lebih pragmatis. Sedangkan karakter Ayah lebih menekankan pada pengalaman subjektif, yakni melakukan verifikasi kebenaran pada "everyday life".

Hubungan relasionalitas di atas terkait dengan beberapa konteks. Konteks disini dimaknai sebagai ruang keseharian manusia. Dalam adegan tersebut dapat dilihat dari perspektif ruang rasionalitas sebagai sistem pemahaman terhadap realitas; (b) Karakter Ain mempertanyakan sang Ayah yang mengajak kamping ke suatu tempat yang merupakan pemandangan alam. Karakter Ayah membenarkan bahwa alam memberikan suasana yang baru dan segar dibandingkan perkotaan yang sudah sumpek. Alam di sini berkaitan dengan slogan feminisme atau ekofeminisme. Slogan ini menerangkan bahwa pohon, air, produksi makanan, hewan, tumbuhan, racun, dan dominasi terhadap alam non-manusia adalah isu feminis (Asmarani, 2018). Namun dalam adegan ini terjadi dekonstruksi ekofeminisme yang dilakukan oleh karakter Ain. Ain lebih memilih di perkotaan dari pada suasana alam. Ekofeminisme berusaha untuk menunjukkan hubungan antara semua bentuk opresi manusia, tetapi juga memfokuskan pada usaha manusia untuk mendominasi dunia bukan manusia, atau alam (Diani et al., 2017).

Di samping itu ada pergeseran ideologi, yakni pergeseran ideologi perkotaan (urban) ke 
ideologi pedesaan (landscape alam) merupakan upaya karakter Ayah untuk menyelesaikan masalah dengan karakter Ain; (c) Pemilihan landscape oleh karakter Ayah bukan hanya karena alasan psikologis, melainkan kesadaran subjektivitas yang merupakan keyakinan yang dihayati dalam hidup sebagai sesuatu yang bernilai. Masing-masing karakter Ayah dan Ain memiliki latar rasional berbeda, yang mana keduanya memiliki habitat dan sistem cara berpikir yang khas. Karakter Ayah berelasi dengan fenomena atau realitas dengan cara menggunakan berpikir mitologi, yakni dimana pemandangan alam, keindahan, menjadi tumpuan dalam kehidupan keseharian. Sedangkan karakter Ain berelasi dengan fenomen atau realitas dengan cara menggunakan berpikir rasional, yakni mengklasifikasikan fenomen berdasarkan perangkat-perangkat konsep logik dan sistem etik. Sistem etik bekerja berdasarkan perangkat logika yang nantinya menjadi orientasi di dalam tindakan atau melakukan tindakan.

Semua hal tersebut yakni pengalaman dan klasifikasi tindakan dapat dipahami dan konkret melalui bahasa. Bahasa yang digunakan oleh karakter ayah yaitu menggunakan alam atau landscape sebagai manifestasi. Karakter Ayah berupaya memberikan pengetahuan dan pengalaman hidupnya pada Ain agar bisa memahami sekaligus memiliki keyakinan akan arti kehidupan. Pandangan dualistik dalam dua karakter tersebut untuk membangun relasionalitas untuk mencapai sebuah harmoni dalam keluarga. Harmoni merupakan pemisahan dan penyatuan dari pertentangan antara ayah dan anak. Perbedaan pandangan tersebut pada akhirnya akan saling membutuhkan dalam meningkatkan nilai mutu hidup yang lebih bermakna.

Film "We Need Talk about Mom” pada dasarnya memiliki tiga unsur modalitas. Pertama; unsur naratif yakni bagaimana mencerminkan sesuatu yang direpresentasikan dan memainkan peran dalam ingatan dan pikiran sebagai idealisasi dan aktualisasi dalam cerita sebuah keluarga. Kedua unsur teknis (mise-en-scene) adalah segala hal yang terletak di depan kamera yang akan diambil gambarnya dalam sebuah produksi film yang memiliki kekuatan sinematik. Unsur teknis (mise-enscene) merupakan strategi dalam film "We Need Talk about Mom" yang membentuk ciri signifikan pada estetika film yang tidak hanya sebagai medium ungkap, namun memiliki pesan yang dikonstruksi melalui bahasa sinematik. Ketiga; unsur kognitif yang merupakan bentuk dari pengetahuan yang dikonstruksi dalam film "We Need Talk about Mom" dan membentuk kesadaran sebagai keyakinan kultural secara normatif melalui nilai-nilai kekeluargaan. 


\section{SIMPULAN}

Film "We Need Talk about Mom" merepresentasikan hubungan keluarga yang menerapkan aspek naratif untuk membangun kesadaran akan pentingnya "kebersamaan" dalam sebuah keluarga melalui perlawanan dengan cara melakukan pembalikan nilai dan evaluasi nilai melalui tokoh Ain dalam cerita tersebut. Nilai-nilai yang ada dalam tokoh Ain merupakan pandangan rasionalitas, sedangkan tokoh Adam (ayah) menggunakan pandangan yang bersifat intuitif dan rasa untuk menyelesaikan masalah.

Makna eksplisit digambarkan lebih pada penyelesaian masalah antara anak dan ayah dengan berbagai perbedaan pandangan (world view), pola gaya hidup, dan nilai-nilai dari setiap tokoh untuk membangun kembali keluarga yang harmonis. Makna implisit yang dihasilkan merupakan relasionalitas sebagai bentuk aktualisasi dan eksistensi dari kedua tokoh yakni Ain dan ayahnya. Sedangkan makna reflektif yang berkaitan dengan simbolisasi sebagai gaya ungkap kreator, serta referensi dan relevansi keilmuan dari penafsir yakni bahwa film "We Need Talk about Mom" menunjukan persoalan cinta, gender, dominasi, dan maskulinitas, dengan demikian film ini ingin menyampaikan semacam strategi membuka yang tersembunyi. Sedangkan wacana dalam pergeseran ruang tersebut, adanya radikalisasi tentang posisiposisi yang tadinya terhierarki, lalu melawan hierarki yang ditunjukkan pada motif-motif dalam adegan film tersebut khususnya yang dilakukan oleh karakter Ain (anak) terhadap Ayahnya, dengan demikian film tersebut ingin menyampaikan kritik terbuka yang lebih kontemplatif.

Terlepas dari kelebihan dan kekurangan film "We Need Talk about Mom" ini, Penelitian film dilakukan sebagai upaya untuk memahami, memaknai, dan mengapresiasi karya film indie sebagai upaya mendukung peningkatan peran aktif dan produktif penonton film dalam meningkatkan pengetahuan dan nilai-nilai budaya yang dapat diterapkan ke dalam sebuah keluarga.

\section{DAFTAR PUSTAKA}

Aartsen, J. (2017). Film World Indonesia The Rise After The Fall. In Film. Universiteit Utrecht.

Asmarani, N. N. O. (2018). Ekofeminisme dalam Antroposen: Relevankah? Kritik terhadap Gagasan Ekofeminisme. BALAIRUNG: Jurnal Multidisipliner Mahasiswa Indonesia, 1(1), 128.

Barker, C. (2018). Cultural Studies Teori dan Praktek (H. Purwanto (ed.); Revisi edi). Kreasi Wacana.

Belasunda, R. (2018). Makna Dalam Teks Film Indie Bandung Pascareformasi: Sebuah Analisis Hermeneutika. In Disertasi (Issue April). Institut Teknologi Bandung.

Danesi, M. (2012). Pesan, Tanda, dan Makna: 
Buku Teks Dasar Mengenai Semiotika dan Teori Komunikasi. In A. Adlin (Ed.), Yogyakarta: Jalasutra (Revisi edi). Jalasutra.

Diani, A., Lestari, M. T., \& Maulana, S. (2017). Representasi Feminisme Dalam Film Maleficent. ProTVF, 1(2), 139-150.

Febriyanti, D., Ramdhani, M., \& Lubis, F. M. (2020). Representasi peran Ibu dalam film Ibu Maafkan Aku. ProTVF, 4(1), 105. https://doi.org/10.24198/ptvf.v4i1.24193

Hidayat, D., Rosidah, Z., Retnasary, M., \& Suhadi, M. (2019). Nilai-nilai kearifan lokal pada unsur naratif dan sinematik film Jelita Sejuba. ProTVF, 3(2), 113. https:// doi.org/10.24198/ptvf.v3i2.21264

Hidayat, H. N., Sudardi, B., Widodo, S. T., \& Habsari, S. K. (2021). Menggali Minangkabau dalam film dengan miseen-scene. ProTVF, 5(1), 117. https://doi. org/10.24198/ptvf.v5i1.29433

Mulyana, D. (2008). Komunikasi Efektif : Suatu Pendekatan Lintas Budaya. Bandung:
Remaja Rosdakarya.

Pratista, H. (2017). Memahami Film (E. Damayati (ed.); kedua). Homerian Pustaka. Putri, I. P. (2017). Mendefinisikan Ulang Film Indie: Deskripsi Perkembangan Sinema Independen Indonesia. Jurnal Komunikasi Indonesia, 2(2), 119-128. https://doi. org/10.7454/jki.v2i2.7838

Putri, N. E., Hakim, N., \& Yamin, M. (2016). Ecologicall Footprint and Biocapacity Analysis for Flooding Prevention in South Sumatera. Jurnal Mimbar, 32(1), 58-64.

Ricoeur, P.(2012). Teori Interpretasi, Memahami Teks, Penafsiran, dan Metodologinya. In D. Muhammed (Ed.), Jogjakarta: IRCiSoD. IRCiSoD.

Saidi, A. (2008). Hermeneutika, Sebuah Cara Untuk Memahami Teks. Jurnal Sosioteknologi, 7(13), 376-382-382.

Sutorini, M. P., Alif, M., \& Sarwani, S. (2019). Semiotika Gender dalam Film Brave. ProTVF, 3(1), 101. https://doi. org/10.24198/ptvf.v3i1.21246 